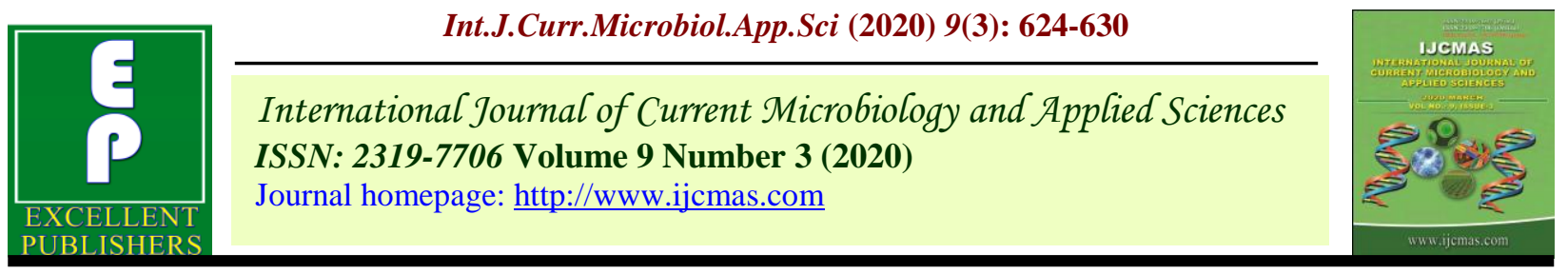

Original Research Article

https://doi.org/10.20546/ijcmas.2020.903.074

\title{
Heterosis for Earliness and Heat Tolerant Trait in Bread Wheat [Triticum aestivum (L.)] over the Environments
}

\author{
Meenakshi Dhoot ${ }^{1 *}$, Hemlata Sharma ${ }^{1}$, Varun Kumar Badaya ${ }^{1}$ and Rupal Dhoot $^{2}$ \\ ${ }^{1}$ Department of Plant breeding and Genetics, Rajasthan College of Agriculture, \\ MPUAT, Udaipur, Rajasthan, India \\ ${ }^{2}$ Department of Genetics and Plant breeding, College of Agriculture, \\ AU, Jodhpur, Rajasthan, India \\ *Corresponding author
}

\begin{tabular}{l} 
K e y w o r d s \\
better parent \\
heterosis, economic \\
heterosis, heat \\
tolerant traits, wheat \\
\hline Article Info \\
Accepted: \\
05 February 2020 \\
Available Online: \\
10 March 2020
\end{tabular}

\section{A B S T R A C T}

Tools for yield prediction are requisite to any successful heterosis breeding program. In this study, heterosis was evaluated by 42 crosses develop by line $\mathrm{x}$ tester design (14 lines and 3 testers) along with 2 checks in RBD with 3 replications in wheat for earliness and heat tolerant traits viz., days to 50 per cent flowering, heat injury, proline content and total chlorophyll content on pooled basis. The pooled analysis for above characters revealed that mean squares due to environments, genotypes, parents, crosses as well as parents $v / s$. crosses were significant indicating presence of overall heterosis for these traits. Out of forty two crosses, six crosses for days to 50 per cent flowering, 1 cross for heat injury, 2 crosses for proline content and 3 crosses for total chlorophyll content expressed desirable significant betterparent heterosis. In case of economic heterosis, one different cross showed desirable significant economic heterosis for days to 50 per cent flowering, heat injury and proline content.

\section{Introduction}

Bread wheat [Triticum aestivum(L.) em. Thell] is the most important food crop in the world which belongs to genus Triticumand family Poaceae. The species of genus Triticumto which the cultivated wheat belongs are divided into diploid, tetraploid and hexaploid groups, with chromosome number
$2 \mathrm{n}=14,28$ and 42 , respectively. These 21 chromosomes of the hexaploid wheat have been divided into seven homeologous group, each homeologous group having a partially homologous chromosome from each of the A, $\mathrm{B}$, and $\mathrm{D}$ genomes.

Heterosis is common in self-pollinated crops such as wheat, providing an option for 
commercial utilization of wheat (Singh et al., 2004). According to Rauf et al., (2012) manipulation of heterosis is an important strategy for increasing the yield potential of wheat. The genetic improvement in wheat genotypes for high yielding potential is a dire need. For fulfil this purpose, the exploitation of maximum genetic potential from available desirable genetic resources of wheat is a prerequisite.

\section{Materials and Methods}

The experimental material comprised of seventeen wheat genotypes (14 lines and 3 testers) and two check varieties viz., MP 3288 and HI 1544. The genotypes were selected on the basis of their origin, adaptability, diversity and morpho-physiological characters viz., earliness, high yield potential and heat tolerance.

These genotypes were crossed in Line $x$ Tester design to develop a total forty two crosses during rabi 2016-17. All the 61 genotypes (17 parents, 42 crosses and 2 checks) were evaluated in a randomized block design with three replications in three different environments during rabi 2017-18 at Department of Genetics and Plant Breeding, Rajasthan College of Agriculture (RCA), MPUAT, Udaipur. Each genotype was accommodated in one row plot of 3 meter length. Row to row and plant to plant distances were $22.5 \mathrm{~cm}$ and $10 \mathrm{~cm}$, respectively.

Heterobeltiosis and economic heterosis, expressed as per cent deviation toward desirable direction over better parent and standard check, respectively. Heterobeltiosis and economic heterosis were calculated according to the method suggested by Fonseca and Patterson (1968) and Meredith and Bridge (1972), respectively.

\section{Results and Discussion}

The pooled analysis for above characters revealed that mean squares due to environments, genotypes, parents, crosses as well as parents $v / s$. crosses were significant indicating presence of overall heterosis for these traits. Mean squares due to genotypes $x$ environments interactions were significant for all the characters above characters reflecting influence of different environments on the expression of genotypes.

The mean squares due to crosses $x$ environments were significant for above characters indicated that crosses interacted differentially with different environments for these characters. The mean squares due to parents $\mathrm{x}$ environments were significant for proline content and total chlorophyll content. This suggested that parents performed differentially in different environments for these characters.

The mean squares due to parents $v / s$ crosses $\mathrm{X}$ environments were significant for only proline content suggested that the average performance of crosses was different from that of the parents in different environments and existence of overall heterosis for these traits. Similar results were also reported by Ameen 2012, Barot et al., 2013,Lohithaswa et al., 2014, Singh et al., 2014, Ismail 2015, Jat et al., 2015, Verma et al., 2016,Kumar et al., 2017 and Singh et al., 2018.

\section{Days to 50 per cent flowering}

Among parents, DBW-71 and Raj 4120 found earliest in $\mathrm{E}_{1}$ (75.33 days), while Raj 4120 also expressed minimum days to 50 per cent flowering in $\mathrm{E}_{2}$ (73 days) and $\mathrm{E}_{3}$ (68.33 days). Among crosses, earliest flowering was observed for HUW-677 x RAJ 4037 in $\mathrm{E}_{1}$ (71 days); HS-547 x RAJ 4037, HUW-677 x RAJ 4037 and DBW-179 x RAJ 4079 in $\mathrm{E}_{2}$ (69.67 
days) and GW-463 x RAJ 4120 and HPW$360 \times$ RAJ 4037 in $E_{3}$ (67.33 days). On pooled basis, parent RAJ 4120 showed minimum days to 50 per cent flowering (72.22 days) followed by parent DBW-71 and RAJ 4037 (73.11 days), parents DBW 129 and RAJ 4079 (73.67 days). While among crosses, cross HS-547 x RAJ 4037 expressed minimum days to 50 per cent flowering (70.22 days) followed by cross HUW $677 \mathrm{x}$ RAJ 4037 (70.33 days), HS 595 x RAJ 4037 (70.67 days) and HPW 360 x RAJ 4037 (70.78 days).

The estimates of heterobeltiosis for days to 50 per cent flowering revealed that out of forty two crosses, 5, 7, 6 crosses exhibited negative significant heterobeltiosis in $\mathrm{E}_{1}, \mathrm{E}_{2}$ and on pooled basis respectively. Maximum negative significant heterobeltiosis for days to 50 per cent flowering expressed by HUW-677 x RAJ $4037(-7.79 \%)$ in $\mathrm{E}_{1}$, crosses HS-547 x RAJ 4037, HUW-677 x RAJ 4037, DBW-179 x RAJ $4079(-5.00 \%)$ in $\mathrm{E}_{2}$ and HS-547 $\mathrm{x}$ RAJ $4037(-3.95 \%)$ on pooled basis. While none of the crosses exhibited negative significant heterobeltiosis in E3 environment. The magnitude of heterobeltiosis for this trait varied from $-3.95 \%$ (HS-547 x RAJ 4037) to $2.26 \%$ (HUW-677 x RAJ 4079) on pooled basis. The negative significant economic heterosis for days to 50 per cent flowering was expressed by cross HUW-677 x RAJ $4037(-5.33 \%)$ in $\mathrm{E}_{1}$ and HS-547 x RAJ 4037 $(-1.71 \%)$ over the earliest check HI-1544 on pooled basis.

\section{Heat injury}

Among parents, minimum mean values for heat injury were recorded for parent HPW 360 in $\mathrm{E}_{1}(30.03 \%)$ and $\mathrm{E}_{2}(32.3 \%)$, while parent RAJ 4120 in $\mathrm{E}_{3}(34.02 \%)$. Among crosses, cross HS-595 x RAJ 4120 in $\mathrm{E}_{1}$ (29.73\%), cross HPW-360 x RAJ 4120 in $\mathrm{E}_{2}$ (31.06 \%) and cross HS-595 x RAJ 4037 in
$\mathrm{E}_{3}(32.52 \%)$ had minimum heat injury. On pooled basis parent HPW-360 had minimum heat injury (32.68\%) followed by RAJ-4120 (32.73\%), DBW-17 (32.94\%) and HPW-368 $(32.98 \%)$. While among crosses, cross HPW360 x RAJ 4120 had minimum mean value for heat injury $(31.23 \%)$ followed by cross HS-595 x RAJ 4037 (31.28\%) and cross HS595 x RAJ 4120 (32.56\%).

One cross HS-595 x RAJ 4037 was expressed negative significant heterobeltiosis for heat injury in $\mathrm{E}_{3}$ with magnitude of $-9.40 \%$. Heterobeltiosis was negative significant for cross HS-595 x RAJ 4037 over the environments with magnitude of $-8.58 \%$ for heat injury. The negative significant economic heterosis was exhibited by only one cross HPW-360 x RAJ 4120 (-4.39\%) over the best check MP 3288 for this trait on pooled basis.

\section{Proline content}

Among parents $\mathrm{PBW}-701$ in $\mathrm{E}_{1}(18.06 \mu \mathrm{g})$ and HS-595 in $\mathrm{E}_{2}(21.69 \mu \mathrm{g}), \mathrm{E}_{3}(24.34 \mu \mathrm{g})$ had maximum mean values for proline content. Similarly, among crosses PBW-701 x RAJ 4120 in $\mathrm{E}_{1}(18.67 \mu \mathrm{g})$, HS-595 x RAJ 4120 in $\mathrm{E}_{2}(21.07 \mu \mathrm{g})$ and HUW-677 $\mathrm{x}$ RAJ 4037 in $\mathrm{E}_{3}(27.74 \mu \mathrm{g})$ showed maximum proline content.

Parent HS-595 showed maximum mean values for proline content $(21.31 \mu \mathrm{g})$ on pooled basis followed by PBW- 701 (20.57 $\mu \mathrm{g}), \mathrm{HPW}-360 \quad(19.10 \mu \mathrm{g})$ and DBW-93 $(18.86 \mu \mathrm{g})$. Among crosses, cross HS-595 x RAJ $4120(21.86 \mu \mathrm{g})$ followed by PBW-701 x RAJ $4120(21.36 \mu \mathrm{g})$ and HUW-677 x RAJ $4037(21.07 \mu \mathrm{g})$ expressed maximum mean values for proline content. The range of proline content over the environments for parents varied from $13.04 \mu \mathrm{g}$ (HPW-368) to $21.69 \mu \mathrm{g}$ (HS-595) and in crosses from 11.26 $\mu \mathrm{g}$ (HPW-368 x RAJ 4079) to $21.86 \mu \mathrm{g}$ (HS595 x RAJ 4120). 
Heterosis over better parent was significant for 2,1 and 6 crosses in $E_{1}, E_{2}$ and $E_{3}$, respectively. The maximum positive significant heterobeltiosis for proline content was depicted by cross HUW-677 x RAJ 4037 in $\mathrm{E}_{1}(9.59 \%)$ and $\mathrm{E}_{3}(28.11 \%)$ whereas cross DBW 179 x RAJ 4079 (8.92 \%) in $\mathrm{E}_{2}$. On pooled basis, 2 crosses viz., HUW $677 \mathrm{x}$ RAJ 4037 (14.97\%) and PBW-701 x RAJ $4120(3.82 \%)$ expressed positive significant heterobeltiosis.

For proline content, the economic heterosis was positive significant for 1,2 and 5 crosses in $E_{1}, E_{2}$ and $E_{3}$,respectively. The maximum economic heterosis was expressed by cross PBW $701 \times$ RAJ 4120 (4.88 \%) in $\mathrm{E}_{1}$, HS 595 $x$ RAJ $4120(5.95 \%)$ in $\mathrm{E}_{2}$ and HUW $677 \mathrm{x}$ RAJ 4037 (14.00 \%) in $\mathrm{E}_{3}$ for this trait. Cross also showed positive significant economic heterosis for proline content over the best check MP 3288 on pooled basis.

\section{Total chlorophyll content}

The mean values for chlorophyll content for both parents and crosses were higher in environment $E_{2}$ as compared to environment $\mathrm{E}_{1}$ and $\mathrm{E}_{3}$. Among parents, RAJ 4037 in $\mathrm{E}_{1}$ $(1.91 \mathrm{mg} / \mathrm{g})$, RAJ 4120 in $\mathrm{E}_{2}(2.2 \mathrm{mg} / \mathrm{g})$ and HPW 360 in $E_{3}(1.84 \mathrm{mg} / \mathrm{g})$ showed maximum mean values for chlorophyll content. While, among crosses, cross HS-595 $x$ RAJ 4037 was expressed maximum chlorophyll content $2.27 \mathrm{mg} / \mathrm{g}$ in $\mathrm{E}_{1}, 2.39$ $\mathrm{mg} / \mathrm{g}$ in $\mathrm{E}_{2}$ and $2.12 \mathrm{mg} / \mathrm{g}$ in $\mathrm{E}_{3}$ environment. The range of chlorophyll content over the environments among parents varied from 1.03 $\mathrm{mg} / \mathrm{g}$ (DBW 71) to $1.94 \mathrm{mg} / \mathrm{g}$ (HPW 360) and among crosses from $1.02 \mathrm{mg} / \mathrm{g}$ (DBW-179 x RAJ 4037 and DBW-71 x RAJ 4079) to 2.26 $\mathrm{mg} / \mathrm{g}$ (HS-595 x RAJ 4037).

Table.1 Pooled Analysis of variance for various traits in wheat

\begin{tabular}{|c|c|c|c|c|c|c|}
\hline SN & Source & Df & $\begin{array}{c}\text { Days to } 50 \\
\text { per cent } \\
\text { flowering }\end{array}$ & $\begin{array}{c}\text { Heat } \\
\text { injury } \\
(\%)\end{array}$ & $\begin{array}{l}\text { Proline content } \\
\text { ( } \mu \text { g per100 } \mathrm{mg} \text { ) }\end{array}$ & $\begin{array}{l}\text { Total Chlorophyll } \\
\text { content }(\mathrm{mg} / \mathrm{g})\end{array}$ \\
\hline 1. & Environment & 2 & $2170.86^{* *}$ & $1200.76 * *$ & $2589.19^{* *}$ & $3.23 * *$ \\
\hline 2. & Rep./Env & 6 & 1.33 & 5.86 & 0.60 & 0.01 \\
\hline \multirow{6}{*}{3.} & Genotype & 60 & $12.29 * *$ & $158.61 * *$ & $59.75^{* * *}$ & $0.96 * *$ \\
\hline & Parent & 16 & $4.96^{* *}$ & $116.86^{* * *}$ & $55.76^{* *}$ & $0.68 * *$ \\
\hline & Tester & 2 & $4.78 * *$ & $48.69 * *$ & $13.94^{* *}$ & 0.01 \\
\hline & Line & 13 & $2.85^{* * *}$ & $127.27 * *$ & $66.47 * *$ & $0.51 * *$ \\
\hline & $\mathrm{P}$ v/s C & 1 & $154.36^{* *}$ & $721.03 * *$ & $14.05^{* *}$ & $0.06^{* *}$ \\
\hline & Cross & 41 & $11.48^{* *}$ & $158.70 * *$ & $62.60^{* * *}$ & $0.94 * *$ \\
\hline \multirow[t]{6}{*}{4.} & Gx E & 120 & $4.46^{* * *}$ & $6.04 * *$ & $4.08^{* *}$ & $0.02 * *$ \\
\hline & $P \times E$ & 32 & 2.19 & 6.20 & $3.27 * *$ & $0.02 * *$ \\
\hline & $T \times E$ & 4 & 0.89 & 2.05 & $2.02 * *$ & $0.03 * *$ \\
\hline & L x E & 26 & 2.39 & $6.62 *$ & $3.14 * *$ & $0.02 * *$ \\
\hline & $\mathrm{P} v / \mathrm{s} \mathrm{C} \times \mathrm{E}$ & 2 & 3.97 & 2.22 & $11.28^{* * *}$ & 0.01 \\
\hline & Cross x E & 82 & $5.47 * *$ & $6.33 * *$ & $3.93^{* *}$ & $0.01 * *$ \\
\hline 5. & Pooled Error & 360 & 2.85 & 4.31 & 0.38 & 0.01 \\
\hline
\end{tabular}

*,** Significant at 5 and 1 per cent, respectively. 
Table.2 Maximum desirable significant heterosis over better parent (BP) and standard check (SC) for days to 50 per cent flowering, heat injury, proline content and total chlorophyll content on pooled basis

\begin{tabular}{|l|l|l|}
\hline Characters & Maximum heterobeltiosis & $\begin{array}{l}\text { Maximum } \\
\text { heterosis }\end{array}$ \\
\hline $\begin{array}{l}\text { Days to 50 per cent } \\
\text { flowering }\end{array}$ & HS-547 x RAJ 4037 (-3.95\%) & HS-547 x RAJ 4037 (-1.71\%) \\
\hline Heat injury & HS-595 x RAJ 4037 (-8.58\%) & $\begin{array}{l}\text { HPW-360 x RAJ4120 (- } \\
4.39 \%)\end{array}$ \\
\hline Proline content & HUW 677 x RAJ 4037 (14.97\%) & HS 595 x RAJ 4120 (2.95\%) \\
\hline Total chlorophyll content & PBW 701 x RAJ 4120(19.05\%) & - \\
\hline
\end{tabular}

Crosses 3, 1 and 3 are expressed positive significant heterosis over the better parent in $E_{1}, \quad E_{2}$ and $E_{3}$, respectively for total chlorophyll content. The maximum heterobeltiosis was observed in cross PBW $701 \times$ RAJ $4120(30.74 \%)$ in $\mathrm{E}_{1}$ and $(24.65 \%)$ in $\mathrm{E}_{3}$ while HS $595 \times$ RAJ $4037(15.48 \%)$ in $\mathrm{E}_{2}$ for this trait. Heterobeltiosis was significant for 3 crosses on pooled basis for total chlorophyll content with maximum magnitude of $19.05 \%$ (PBW $701 \times$ RAJ 4120) for this trait. None of the crosses showed significant economic heterosis for this trait in any of the environments.

Similar findings were obtained bySaxena and Rawat 2011, Jain and Sastry 2012, Singh et al., 2012, Beche et al., 2013, Desale and Mehta 2013, Singh et al., 2013,Barot et al., 2014,Gogas and Sotiriou 2014, Kumar and Kerkhi 2014, Ismail 2015, Kalhoro et al., 2015, Desale et al., 2016, Kumar et al., 2016, Thomas et al., 2017, Yadav et al., 2017, Patel 2018, Rajput and Kandalkar 2018,Saini et al., 2018 and Saren et al., 2018.

\section{References}

Ameen, T.E. 2012. Stability analysis of selected wheat genotypes under different environment conditions in Upper Egypt. African Journal of Agricultural Research, 7: 4838-4844.
Barot, H. G., Patel, M. S., Sheikh, W.A., Patel L.P. and Allam, C.R. 2014. Heterosis and combining ability analysis for yield and its component traits in wheat [Triticum aestivum (L.)]. Electronic Journal of Plant Breeding, 5: 350-359.

Beche Eduardo, Silva Cristiano Lemes da, Pagliosa Eduardo Stefani, Capelin Marcio Andrei, JeissonFranke, GilvaniMatei, Benin Giovani 2013. Hybrid performance and heterosis in early segregant populations of Brazilian spring wheat. Australian Journal of Crop Science, 7:51-57.

Desale, C. S., Mehta, D. R. and Patel, N. B. 2016. Heterosis in Bread Wheat (Triticum aestivum L.). Agres - An International e-Journal, 5: 52-59.

Desale, C.S. and Mehta, D.R. 2013. Heterosis and combining ability analysis for grain yield and quality traits in bread wheat (Triticum aestivum L.). Electronic Journal of Plant Breeding, 4: 12051213.

Fonesca, S. and Patterson, F. L. 1968. Hybrid vigour in seven-parental diallel crosses in common winter wheat (Triticum aestivum L.). Crop Science, 8: 85-88.

Ismail, K. and Samier,A. 2015. Heterosis and combining ability analysis for yield and its components in bread wheat (Triticum aestivum L.). International Journal of Current Microbiology and Applied 
Sciences, 4: 1-9.

Jain, S.K. and Sastry, E.V.D. 2012. Heterosis and combining ability for grain yield and its contributing traits in bread wheat (Triticum aestivum L.). Research and Reviews, 1: 17-22.

Jat, B. S., Ranwah, B. R., Bharti, B. and Parihar, A. K. 2015. Stability analysis to ascertain the performance of different genotypes of wheat [Triticum aestivum L.]. The Bioscan, 10: 929-933.

Kalhoro, F. A., Rajpar, A. A., Kalhoro, S. A., Mahar, A., Ali, A., Otho, S. A., Soomro, R. N., Ali, F. and Baloch, Z. A. 2015. Heterosis and combing ability in $F_{1}$ population of hexaploid wheat (Triticum aestivum L.). American Journal of Plant Science, 6: 1011-1026.

Kumar Dinesh and Kerkhi S. A. 2014.Heterosis studies for yield component traits andquality in spring wheat (Triticum aestivum L.). Bioscan,9: 1725-173.

Kumar Jaydev, Singh S.K., Singh Lokendra, Kumar Mukul, Kumar Anuj, Kumar Arun, Kumar Sarvan and Yadav RK 2016. Study of economic heterosis and inbreeding depression in bread wheat (Triticum aestivum L.) under late sown condition. Research in Environment and Life Sciences, 9: 1082-1086.

Kumar S., Singh S.K., Singh L., Gupta S.K., Vishwanath, Yadav P., Yadav P.C., Pandey Y., Singh L. and Kumar S. 2017. Heterosis and Inbreeding Depression for Grain Yield and related Morphophysiological Characters in Wheat (Triticum aestivum L.). International Journal of Current Microbiology and Applied Sciences,6: 1352-1364.

Lohithaswa H.C., Desai S.A., Hanchinal R.R., Patil B.N., Math K.K., KalappanavarI. K., Bandivadder T. T. and Chandrashekhara, C. P. 2014. Combining ability in tetraploid wheat for yield, yield attributing traits, quality and rust resistance over environments. Karnataka Journal of Agricultural Research, 26: 190-193.

Meredith, W. R. and Bridge, R. R. 1972. Heterosis and gene action in cotton (Gossypium hirsutam). Crop Science, 12: 304-310.

Patel H. N. 2018.Identification of Heterotic Combinations for Grain Yield and Quality Traits in Bread Wheat (Triticum aestivum L.). International Journal of Pure and Applied Biosciences, 6: 107115.

Rajput Rahul Singh and Kandalkar VS 2018. Combining ability and heterosis for grain yield and its attributing traits in bread wheat (Triticum aestivum L.).Journal of Pharmacognosy and Phytochemistry, 7: 113-119.

Rauf, S., Shahzad, M., Teixeira da Silva, J. A. and Noorka, I.R. 2012. Biomass partitioning in sunflower (Helianthus annuus L.) inbred lines and hybrids under contrasting saline regimes. Journal of Crop Science and Biotechnology, 15: 53-57.

Saini Pawan Kumar, Kumar Sarvendra and Singh SV 2018. Heterosis for grain yield and its contributing traits in bread wheat ( $T$. aestivumL.). International Journal of Chemical Studies, 6: 284287.

SarenDebashis, Mandal AsitBaran, Soren Chaitan 2018. Heterosis studies in bread wheat (Triticum aestivum L.). Journal of Agriculture and Veterinary Science, 11: 80-84.

SaxenaPayal and Rawat R.S. 2011. Combining ability and heterosis for yield and quality traits in bread wheat (Triticum aestivum L.em.Thell). Pantnagar Journal of Research, 9: 170177.

Singh Mamta, Devi E. Lamalakshmi, Aglawe Supriya, KousarNagma and Behera 
Chandana 2013. Estimation of heterosis in different crosses of breadwheat (Triticum aestivum L.). Bioscan, 8: 1393-1401.

Singh Vikrant, Ram Krishna, Singh Sanjay and Vikram Prashant 2012.Combining ability and heterosis analysis for yield traits in bread wheat (Triticum aestivum). Indian Journal of Agricultural Sciences 82: 916-21.

Singh, H., Sharma, S. N. and Sain, R. S. 2004. Heterosis studies for yield and its components in bread wheat over environments. Hereditas, 141:106-114.

Singh, M. K., Sharma, P. K., Tyagi, B. S. and Singh, G. 2014. Heterosis for Yield Component Traits and Protein Content in Bread Wheat under Normal and Heat-stress Environment. Cereal Research Communications, 42: 151162.

Singh C., Srivastava P., Sharma A., Kumar P.,
Chhuneja P., Sohu V.S. and Bains N.S. 2018. Stability analysis for grain yield and some quality traits in bread wheat (Triticum aestivum L.).Journal of Applied and Natural Science, 10: 466474.

Thomas, N., Marker, S., Lal, G. M. and Dayal, A. 2017. Study of heterosis for grain yield and its components in wheat (Triticum aestivum L.) over normal and heat stress condition. Journal of Pharmacognosy and Phytochemistry, 6: 824-830.

Yadav Jyoti, Sharma Satya Narayan and Shweta 2017.Heterosis and Inbreeding Depression Analysis for Yield and its Components Traits in Bread Wheat (Triticum aestivum L. em. Thell.) Over Environments.International Journal of Pure and Applied Biosciences, 5: 9951003.

\section{How to cite this article:}

Meenakshi Dhoot, Hemlata Sharma, Varun Kumar Badaya and Rupal Dhoot. 2020. Heterosis for Earliness and Heat Tolerant Trait in Bread Wheat [Triticum aestivum (L.)] over the Environments. Int.J.Curr.Microbiol.App.Sci. 9(03): 624-630. doi: https://doi.org/10.20546/ijcmas.2020.903.074 